\title{
THE REPRESENTATION OF FEMALE CHARACTER IN EDGE OF TOMORROW (2014) FILM BASED ON FEMINIST FILM CRITICS
}

\author{
Lana Prismanisa \\ University of Jakarta \\ email: lanaprismanisa@gmail.com
}

\begin{abstract}
(Title: The Representation of Female Character in "Edge of Tomorrow" (2014) Film Based on Feminist Film Critics). This research analyzes the female character in Edge of Tomorrow, Rita Vrataski. It intends to understand how female character is described in the film according to feminist film criticism. The method used is the descriptive qualitative method. This research also uses theory character and characterization in film and theory feminist film critic. As the result, Rita is described as a female soldier who has characteristics as committed, brave, assertive, strong, muscular, intelligent, and skillful soldier. Even though Rita, as the female character, has man's characteristics, she still needs help from another male character. Rita character in this film is still passive because the one who finishes the mission in the story is the male character, William Cage. This film proves that male domination still exists and the female stereotype is difficult to change.
\end{abstract}

Keywords: female character, women in film, feminist film critic

\section{INTRODUCTION}

Women have important role in fundamental function of human life. Only women can be pregnant (Levit 69). The roles of women are not only to childbearing, but also in taking care of their children and women have a duty to organize their household (McHugh 5). Besides having responsibility as mother and as wife, women also presented as a complementary in men's life. Women as housewives should follow their husband because they are the heads of the family.

In social life the position of men is higher than women. Women's role is often connected to the private space; they are staying at home and work without paid. While, men exist in the public space; they work as professional and get paid. The difference between women and men is not only seen by their position in social existence, but also by their different physic and characteristic. As explained by Nussbaum women are less well-nurtured than men as women have a weak body, defenseless, and often become the victims of physical ferocity and social abuse (I). The existence of women in life is only becomes the oppressed people and men's satisfaction.
In the early eighteenth century, there is a movement about women named Feminism. In general, feminism is women's Liberation Ideology. This movement is the form of renewal tradition concept and questioning about inequality of the position of women in social (Barry 143). According to Waugh, "feminism begins with liberalism, when women demand equality with men; the reacting against equality feminism, radical feminists reject patriarchy in favor of separatist matriarchy; finally women come to reject altogether the difference between masculine and feminine as metaphysical" (337). In the other words, this movement is the awareness of women about their identity to destruct the hierarchy that is harmful for women's position. Moreover feminist has worked hard to advance the level of women in social and politic field.

The women movement above becomes the basic formation of feminist literary criticism, because feminist criticism believes that this movement contains elements of literature. The significant image of women is distributed through literature (Barry 143). The stereotypes in which woman are mentally weak, frequently being the victim of physical 
violence and identically working only in the house in the human life is also applied in a literary work. Aligned with that idea, from the article entitled The Woman in Modernism, women have been seen and treated more as complements to the men in their lives than as individuals or spiritual entities; women are depicted in literature as feminine, weak, dutiful, and thoughtless (Wrenn).

Moreover, types of story are also stereotypical. There is an argument that the certain genres of story such as epic embody masculine values of heroism, war, and adventure. On the other hand, the mellow drama and musical have sometimes identically with feminine, (Habib 68). In fact, woman in story of film is unpresented. Woman, in any fully human form, have almost completely been left out of film. This is not surprising, since role of women in literature never showed up (Smith 14). Indeed, the film industry generally treats women's self-definition as though it hinges on sexual or loving relations with men (Dittmar 6). Almost same in real life, the presence of women in film is also as supplementary of men. The term 'women' has obtained its meaning within sexist, or patriarchal, ideology. It has meaning only within that structure. Thus, it is pointless to compare film stereotype of women in film with the reality of women's lives (Smith, 12). Feminism is a social movement that has had an enormous impact in film theory and criticism.

The feminist film critic which has a root from a feminist film debate in late 19th century can be called as a movement which gives a space to feminist to explain how women are represented and positioned in film - they get an active or passive role (McCabe 18). Feminist film critics examined the question of feminine identity and the representation of women in film as the site/sight or object of exchange between men (Hayward 135).

Particularly, according to Knight, feminist film theory is very much political in nature. "It seeks to expose, not to perpetuate, patriarchal practices". It is about fighting for equal rights for women as a distinct social group, equal to men in every way (39). Because of the women's rights movement, feminists argue that female portrayals in the media should change. King argues, "as women assume authorial control and industrial power, and as audiences demand new images in old-fashioned genres, the representation of women should continue to change"(2). Meanwhile, cinema is a cultural practice where myths about women and femininity, and men and masculinity, in short, myths about sexual difference are produced, reproduced, and represented (Smelik 8),

The role of woman in film almost always resolves around her physical attraction and the mating games she plays with male characters. Women provide trouble or sexual interludes for male character, or are not all present at all. Even when a woman is central character she generally shown as confused or helpless and in danger or passive or as a purely sexual being. It just seems odd that these few images and others like them are all we see of women almost every film since very few film makers given much thought to their habits of sex-role stereotyping, even a film which has one strong female (Smith15). Film usually gives an active role to man character while female character is given passive role. This situation continuous become convention in the film and repeated on the level of film plot (Fabe 221).

Breaking the text down into smaller units and the analysis which are so detailed until to the hidden textual operation at work in each segment as well as across the whole film text are the ideological analysis which is used by the researcher in analyzing the film. In the feminist film critic, looking for ideological signs and formal contestation in relation to dominant film representations of woman become a focus on the ruptured text (McCabe 18). In the Fifty Key Concept in Gender Studies, the ideology can be concluded as the system belief which holds impact and determines most people's view of social order, but there also oppositional ideologies (such: Marxism, feminism) which seek to change people consciousness, by replacing the dominant version of real condition of existence with their own.

Feminist film critics are using the ideology that has the main goal. In the feminist film critics, looking for ideological signs and formal contestation in relation to dominant film 
representations of woman become a focus on the ruptured text (McCabe 18). The ideology which is used in feminist film critics, basically have the main goal. It is not only made the feminist intervention possible by giving a language to speak, but also to legitimize the feminist theoretical position to standing within current academic thinking (McCabe 16).

In this modern era many filmmakers are interested to make a new revolution about women. Smith said in his essay entitled The Image of Women in Film that "I hope by now it is obvious that women must be shown in a much wider variety of roles. Their characterizations must have heroism and human dignity expressed in fields besides homemaking, loving men, and bearing children"(18). Now days, the woman character becomes role model such as hero in film industries: women do not only presented in mellow drama and romantic film, but also in film that categorized as masculine such as adventure and action. There are some action movies that depict woman character as strong and active. Furiosa in Mad Max:Fury Road film (2015), portrayed as an extraordinary female action character(Cowden). Sarah Connor in Terminator 2: Judgment Day is portrayed as woman warrior who protects her son. The great female action character with her arrow, Katniss Everdeen, in The Hunger games film (2012). Another female action heroin also comes from Edge of Tomorrow (2014) film.

Edge of Tomorrow (the movie adapted from Japanese light novel All You Need is Kill by Hiroshi Sakurazaka) is American scifi action film directed by Dought Liman. The movie begins with the attack of alien race on the earth. The military officer is involved into the war with alien race. The officer Cage is the main character of this movie portrayed by Tom Cruise. The film starts from the news about the attack of aliens name Mimic in some areas. This news is also report about a new invention as a tool in the battle named jacket technology. In the news about the jacket technology, there is woman warrior who becomes the icon of the invention. The woman warrior is Rita Vrataski which is portrayed by Emily Blunt. In the news Rita is using the jacket technology and holding a big sword. Rita is female hero who defeats hundreds of Mimic in Verdun, because of that she is called "Angel of Verdun". Rita is a sergeant and the only woman that appear in this story. She is renowned as humanity's mightiest warrior. She is called as the full metal woman by men warriors. Furthermore, both Rita and Cage get the same experience, they receive the same power — resetting the time-but, Rita loses the power.

Rita is not the main character of this story, but Rita has an important role to help Cage through the combat. She also gives strategy to defeat the combat. There is a part of powerful woman soldier that is considered as a savior and best hope for humanity in this story. Although, the woman character in this story described as strong female character, but the man character still dominate in this story.

In this occasion, it is interested to analyze how Rita as female character in sci-fi action film is presented. In order to understand the depiction of female character in sci-fi action film feminist film critic is the most suitable one to be used in this research. The focus of the research is female character by using feminist film critics. This research focuses on analyzing the character of Rita Vrataski and how is Rita as female character described according to feminist film critic.

\section{METHOD}

This Research methodology includes some aspects of research such as a method research, technique of data analysis, an instrument of research, and unit of analysis. This research used qualitative research. Qualitative research, also called "mutualistic inquiry, developed within the social and human sciences, and refers to theories in interpretation (hermeneutics) and human experience (phenomenology)" (Wahyuni 1). According to the quotation, qualitative research is the terms that related to humans knowledge and social life which is associated into the theories that have created. In this research the material being studied is film as text and this research use some theories to support the data. 
The method being used is descriptive qualitative method. Descriptive research is collecting data then explain the result and the categorizes, arranges, depicts, and desribes the data collection (Knupfer and Mclellan 1197) . The writer uses two data sources primary data source and secondary data source. The primary source of the data collection is the film Edge of Tomorrow. The secondary data are taken from other sources both printed and e-book wich related to primary data and to support the analysis.

The instrument of research is the writer herself by watching the film repeatedly and taking some notes that become the data. In additional, reading the some books and websites to understand, identify, and analyze that related data with feminist approach.

\section{RESULTS AND DISCUSSIONS Results}

Edge of Tomorrow film is representing about female character as warrior in this film. According to the research question how is the female character described in Edge of Tomorrow film? The writer would like to analyze female character Rita Vrataski. In this chapter, the writer wants to point out of female characteristic through some theories that used for analyzing film Edge of Tomorrow. To expose the characterization in the film, the book entitled The Art of Watching Film is written by Joseph Boggs and Deniss Petrie has eight kind of characterization in film. There are characterizations through appearance, Characterization through dialogue Characterization through reaction of other characters, Characterization through external action, Characterization through internal action, Characterization through contrast: Dramatic Foils, Characterization through choice of name. From eight of kind characterization in film, this research would only use seven of them.

Rita Vrataski is the female soldier who wins the battle in Verdun by defeating hundreds of Mimic (aliens). Therefore, she is called as "Angel of Verdun". She becomes one of humanity's hopes to win the battle with the Mimic that happened on earth. Moreover,
Rita Vrataski is the leader of army soldiers at Heathrow. So that she is called Sergeant Rita. Additionally, there is no information about Rita's personal life both family and friends.

Furthermore, the portrayal of Rita as the female soldier is explained through her characteristic based on her physical appearance and personality traits and skill as follow.

Firstly, physical appearance, as the soldier, Rita uses a costume like a soldier in general. She wears soldier uniform like a black jacket with the logo that sticks on the jacket, and long black pant. There is also a big belt on her waist in order to put the gun both sides of her pants. She is also uses a black boot in her feet. When she first meets Cage, she just wears a black tank-top with the training pant. Those kinds of outfit are usually worn by Rita when she is practicing. Moreover, since Rita wins the war, she becomes the icon of one invention called jacket technology. Jacket technology is an invention and becomes the equipment to fight the aliens. The jacket becomes one of the attributes that used by soldiers in battle including Rita. This tool is like jacket that is used on the body. Beside wearing a suit metal, she is also using a metal red vest on her body. The metal red vest is the characteristic of Rita in her battle uniform.

This jacket is basically powered exoskeletons that providing both armor and weapons than enhances the wearer's mobility. This equipment has several functions to survive and attack. Each side of this tool has the weapons to shoot the enemies. In this case, Rita is very skilled in using this tool to attack the alien.

Based on what Rita wears for the first time, she appears in the film until the end, Rita Vrataski is depicted as a soldier woman with a simple style. She wears the outfit that is comfortable with her because she is always in duty. She always uses the outfit with dark color like black, gray, and brown. In this film, Rita is depicted as a woman without make up on her face and always with mess hair. There is no women's accessory in her body such as a ring, an earring, or necklace, because Rita is never presenting out of her duty as soldier. She does 
not paying much attention with what she wears. Rita is described as woman with blue eyes and brown hair. She has a clear face. Along the story, Rita never showed any expression on her face. She always appears with serious face. She has tan skin and little wound on her forehead.

Rita has a muscular body. Rita's height is almost the same with other male soldiers in this film. Rita also has muscles in her arm. It is seen in one scene when Rita is doing a physical exercise with the outfit which shows her muscles in her arms, and her body which is sturdy. In addition, she is also walks very steadily. She walks with sturdy chest, handful, and sure in movement. The gesture of her body always looks like ready to face a dangerous situation in front of her.

Rita has a strong body. In the battle combat, Rita is very skilled using a heavy armor on her body. It is seen when she fights the aliens wearing the jacket and using big sword. She is able to kill all the aliens with the jacket on her body fluently. She also has one special weapon; she always uses a big sword as a weapon to attack the alien. Rita has strong body that is proven when Cage and she are in the middle of their journey, then they find a farm house and decide to take a rest. Rita finds a helicopter next to the farm house. Then, Rita wants to ride the helicopter. But, something bad happens to Rita. She groans painfully when she checks the condition of the helicopter and tries to hold the helicopter blades. She gets injured around her right shoulder. Furthermore, Cage comes near to Rita and asks her what actually happens. Rita lies to Cage by saying nothing happens and she is fine anyway. Even though Rita gets injury around her shoulder, she still wants to keep their trip without worrying the wound on her body. It proves that Rita has a very strong body even when she gets injured; she still has energy to continue their trip.

Secondly, personality traits, Rita as a soldier, Rita is committed soldier. It is seen when she puts her country and her duty as the top of her priority, while she puts herself interest at the last priority. She is willing to sacrifice herself even she would die. Rita's thought of war is something that must be done in earnest, without fear of death and loss of people who close with her. Rita has a strong desire to win the war. For instance, her commitment in duty as the soldier is proven when she is willing to feel the pain in helping Cage defeating the aliens in order to win the war. She totally prepares to fight without worry. Rita is never afraid about what will happen in the middle of her combat. She prefers focusing on the mission to win the war. She makes her own decision to help Cage without compromising herself. Rita is brave woman. It is shown when Cage and she decide to go to the main building of UDF (United Defense Force) name Whitehall. They go there to obtain a prototype that created by Carter. The prototype has function to connect directly to the Omega, so that they can find where the Omega is. The prototype has saved in the office of General Brigham, head of UDF (United Defense Force). Cage and Rita try to go to the office of General Brigham stealthily. When they successfully go into the office, Rita is bravely point out the gun to the General Brigham in order that General Brigham does not call his guard and keeps calming down to listen their explanation and intention. It is shown how bravely she is without thinking the risk she would get.

As committed soldier, she becomes an assertive person. It is proven when Cage still hesitates about the ability he has, Rita resolutely explain him about what he needs to do with his ability. She gives a very detail explanation, so that Cage can understand and believe her that they can work together to find Omega. Rita insists that Cage take her to the place where the Omega is. Furthermore, Rita teaches Cage to be engaged in combat. She helps Cage how to use the jacket technology and how to fight the aliens. Cage becomes able to engage the adversaries with increasing skill alongside Rita Vratsaki. As a soldier, she has an assertive action that makes Cage confident in carrying out the mission with her.From the explanation above, it is proven that Rita is committed soldier who has brave and assertive characteristic.

Rita has strong mentality. Beside she is depicted to have a strong body, she is also 
described to have strong mentality. The strong mentality of Rita it is proven when she is able to watch the death frequently. Rita has strong mentality exists when Rita trains Cage. Once Rita realizes that Cage does not have ability in combat, she trains him and gives him a plan to follow. In practice, every time Cage fails and gets injured, Rita does not hesitate to shoot Cage with the gun to die and come back to repeat the day. Rita must shoot Cage, because if Cage gets an injured and gets treatment he should receive a blood transfusion which is one way to eliminate the ability (reset the time) that Cage received. Rita has no choice therefore she has to point the gun repeatedly to Cage to come a new day. Rita has strong mentality in shooting Cage without hesitate. Moreover, to shoot people with gun need strong mentality to do that, if Rita does not has strong mentality she cannot able to kills and shoot Cage.

Rita is intelligent, Rita is intelligence proven when she knows the information about the alien about the system and the function of the alien. Moreover, she can remember all the instructions and strategies that Cage explain. When Cage has a vision where the omega, Cage and Rita set up strategy to reach the omega, but almost in every halfway Rita is always killed so that makes Cage has to repeat the day many times. Along the journey Cage always tells Rita where the enemy will attack her in the day of the battle so that Rita can anticipate the attack. Cage always explains the instruction clearly where the alien will attack her and where she has to go to avoid the attack. Rita always asks Cage to explain more specifically and Rita is very focus in listen the instruction. Furthermore, with the specific explanation Rita is able to remain all the instruction accurately and can be save in battle combat.

Rita is the committed soldier that intelligent in combat. It is shown when the first time Cage save Rita, Cage gets shot in his chest. Rita takes away the battery from his armor suit. The function of the battery is energy for the armor. In that case, Rita takes the battery from Cage's armor for the backup for her armor. After taking away the battery, she moves on and engages herself fighting with the alien. She is very cleaver in handle the situation in combat. She knows that she needs more ammunition to her metal suit so that she takes Cage's battery.

Third, Skill, Rita also has many skills. Besides, she has ability in use a weapon such a gun and sword. She is also has other skills. It is shown when she takes a drive to run away from alien attack. After she and Cage finish the combat in the first wave on the coast of France they continue their journey to find the omega. They have a plant to distract the alien. In this scene, Rita drives a minivan with the armor on her body, Rita can handle the minivan very well in condition the alien attack her while cage sit beside her.

The other ability of Rita is able to fly the mini helicopter. It is shown when their journey stopped on the way to the omega. They are in the farm house to take a rest. In the farm house there is a mini helicopter, but Cage known that if the machine of the helicopter turn on the alien will attack them. Rita does not care about it, she tries to fly the helicopter without doubt she know how to fly the helicopter.

\section{Discussion}

Feminist Film Critic in Film Edge of Tomorrow. Feminist film criticism wants to change the situation of women's position in a film. Besides being described as a wife; a mother who bears children; or a housewife, a woman also should possess the characteristics of heroism and human dignity (Smith 19). Furthermore, the woman character-Rita Vrataski-in this film is not described as a wife or a mother, instead she is depicted as a woman who has a heroism value. She is portrayed as a soldier who is muscular, strong, brave, committed soldier, intelligent, and skillfull.

Feminist also wants to improve the woman's condition by positioning women become equal to men. According to those all characteristics of Rita Vrataski, the character of Rita is presented having an equal role with the male character named William Cage. The equality can be seen as follows. Firstly, Rita takes the same role as the male character, William Cage. Both Rita and Cage are depicted 
as heroes who defeat a war with alien race. In this film, Rita plays a role which it actually belongs to men's position, such as being a soldier. Being a soldier is identified as a part of patriarchal society. Moreover, the role similarity also appears when both Cage and Rita receive the same power. They get an ability to reset the time. However, unlike Cage, Rita has no longer the ability since she loses it when she in Verdun. Furthermore, in a film, women usually take a place at house as the housewife. However, in this film, the female character is presented in field of war. Both female and male character can work as a team. They can be a good battle partners, so that they can win the war.

Secondly, Rita in the film is almost depicted having similar characteristic with male character in this story. Rita's appearance reflects a man's characteristic. She has muscular body as she has muscle in both her arms. Pronger said in his essay entitled The Arena of Masculinity: Sports, Homosexuality, and the Meaning of Sex that "Muscles have great power; a power consists not only in their ability to move heavy objects but also puissant symbols of man" (48). From the quotation, it is known that muscle is one of the men characteristics. Besides, Rita has very strong and sturdy body like a man. It is proven when she is not really in trouble in using the equipment for the combat. From this case, it can be seen that the image of male body is displayed in Rita Vrataski character.

Moreover, the man's characteristic also exists in Rita through her ability in using a weapon, which is usually used by a man, such as gun and sword. Innes in her book said that "Where the appropriation of the phallus performed by past action heroines has been detailed by their use of masculine characteristics and symbolic accoutrements like guns, swords, and muscles" (Innes, 56). In the other words, both gun and sword are the symbol of man's characteristic. In addition, Rita is also depicted a character who is emotionless, while in a film woman usually plays more emotionally such as crying and getting angry easily. However, there are still some parts of the film that contradict with the equality role of female character and male character. Firstly, in this film Rita is a passive character. Although she is depicted as a female character who is muscular, strong, committed soldier, and intelligent, Rita is always helped by man who is lack in everything. In other words, the ability of Cage in combat is less than Rita's. Cage is the one who always protects and saves Rita. In every danger situation, he always immediately rescues her. From the beginning to the end story, Cage always protects Rita in every situation. Furthermore, the fact that Rita is a passive character is proven when Rita loses her power - in which resetting the time - and leaves Cage to be the only one who has the power. Since then, Rita becomes the character that depends on Cage. Thus, it shows how woman is played passively in this film.

Secondly, the stereotype of woman appears in character Rita Vrataski. The stereotype that appears is about sexual-being. This film, Edge of Tomorrow, presents a woman character that exists in men circles. She is the only woman soldier who appears along the story. Although, Rita is very glorified as a heroine figure who wins the battle and called as "The Angel of Verdun", there are some scenes that show how Rita is looked down as an object of sex. It is proven when the first time Cage finds himself awake in Heathrow station. The first thing that he finds is a bus with poster Rita Vratski on it. And, there is a word on that poster, i.e. "Full Metal Bitch". According to Merriam Webster dictionary the word "Bitch" has a meaning " $a$ lewd or immoral woman, a malicious, spiteful, or overbearing womansometimes used as generalized term of abuse". So it can be concluded that the word "bitch" is an insult to woman because "bitch" usually deals with woman sex worker. In this case, it can be seen how the man character (the man soldier) looks down to woman character sergeant, Rita Vrataski. The stereotype of Rita also appears when Rita goes out from the Heathrow station to take an aeroplan. There are many men soldiers that assemble around her to watch her (Picture 21). Suddenly, there is a soldier that says "Bloody hell, it's the full metal b.." with a mocking tone. Before the man finishes his words, Rita directly hitched him. In this case, the man still looks down to woman even though she is a heroine. 
Thus, the representation of Rita as an object of sex by the male character in this film is relevant with what Tornham states "Even when a woman is strong character woman cannot escape from sexual being. Film is also cannot separated from the habits of sex-role stereotyping, even a film which has one strong female" (Smith 15). From the explanation above, it is proven that a woman in film cannot be separated from sex-role stereotype although she is the strong character.

In brief, the female action character in this film is depicted as heroic, strong, and brave character. Moreover, the female character is presented being equal to the male character. Nevertheless, the woman's dependency over man is still reflected. This film confirms that a film is generally still difficult to overrule the story from female stereotype. In other words, a female character remains dependent on the male character, even when she is showed in an action genre and takes an important role in the story.

\section{CONCLUSION}

To conclude, this research is about analyzing female character Rita Vrataski in sci-fi action film Edge of Tomorrow (2014). Rita Vrataski is not the main character in this film, but she is the only female character that has an important role in helping the major character, William Cage. She is the powerful character. This research aims to understand how Rita as female character described in this sci-fi action film. Rita is the powerful central female character. Rita depicted as soldier who always wears the simple outfit and the heavy attribute. She has muscular body and strong body. She described as committed warrior: the first priority in her life is winning the war even die for her country. As committed warrior Rita is person that brave, and assertive. She also intelligent: she can helping Cage trough the combat. She is also soldier who has good skill in combat.

Moreover, this film tries to present the female character that has equal role and characteristic with the male character. The female character appears in patriarchal society as a leader and takes a man's job. She express in field of war. Moreover, her role does not playing under the man's oppressed anymore, but both female and male character can work together as the hero. Rita's characteristic reflects man's characteristic trough the appearance and skill.

However, the film cannot entirely escape from the stereotypical characteristic of woman. Rita is strong and brave person, but in this film Rita's life still depend on man. In every danger situation Rita still need Cage to help her. There is also stereotype about woman in this film which is woman still be a sexualbeing

Furthermore, the film wants to show the equality between male and female character, but man still dominate in the story of film which is man takes an active role and woman takes a passive role. This film Edge of Tomorrow approves that film is still difficult to aside from female stereotype in spite of the female character is heroin, male character still dominant in this story.

Edge of Tomorrow is American sci-fi action film directed by Dought Liman describes about female character who has masculinity character. The character masculine appears through the physical appearance and personality traits. The woman is Rita Vrataski. She is not only female character who strong and brave, but also she is character who successfully brings the main character to win the war.

To get the right comprehension of the film or literary work itself, researchers should use the right theory in analyzing film or literary work. Edge of Tomorrow film is can be analyzed from many points of view. This film is also talking about time loop. In this chance, the writer uses character and characterization theory and feminist film critic in analyze female character in this film, Rita Vrataski.

\section{REFERENCES}

Allen, R. \& Gomery, D. (1985). Theory and Practice Film History. United States: Originally Published. Print.

Barry, P.(1955). Beginning Theory. Manchester: Manchester University Press

Dittmar, L. (2017). Images of Women in Film: An Introductory Women's Studies 
Course. The Radical Teacher, No.22 (1982), pp 6-9.

Edge of Tomorrow, Dir. Doug Liman. Perf. Tom Cruise, Emily Blunt. Picture, 2014. Film.

Habib, M.A.R. (2005). A History of Literary Criticism. United Kingdom: Blackwell.

Innes, A. S.. (2004). Action Chicks: New Images of Tough Women in Popular Culture. New York: PALGRAVE MACMILLAN.

Knupfer, N. N. and Mclellan, H. (2001). "Descriptive Research Methodologies". The Association for Educational Communications and technology.

Knight, D. (1995). Women, Subjectivity, and the Rhetoric of Anti-Humanisn in Feminist Film Theory. New Literary History.

McCabe, J. (2004) Feminist Film Studies: Writing the Woman into the Cinema. London and New York: Wallflower

McHugh, A. K. (1999). American Domesticity: From How Manual To Hollywood Melodrama. New York: Oxford University Press.
Merriam Webster Incorporated. (2016). Merriam-webster

Nussabaum C. M. (2000). Women and Human Development. Cambridge: Cambridge University Press.

Levit, N. (1998) The Gender Line: Men, Women and The Law. New York: New York University Press.

Petrie, D. and Boggs, J. (2012) The Art of Watching Film Eight Edition. New York: McGraw-Hill.

Pronger, B. (2017). The Arena of Masculinity: Sports, Homosexuality, and the Meaning of Sex: New York. ST. Martin's Press.

Smith, S. (1999). "The Image of Women in Film" Feminist Film Theory: A Reader ed. Sue Thornhamr. Edinburg: Edinburg University Press.

Waugh, P., ed. (2006). Literary Theory and Criticism. United States: Oxfor University.

Works of Jacobs P. Cristopher. (2013). Film Theory and Approaches to Criticism, or, What did that movie mean?. University of Dakota.

Wrenn, H. (2010). The Woman in Modernism. ELF Vol.2. 2010. 